Print- ISSN: 1391-586X, E- ISSN: 2602-9030, Copyright @ 2017 by Faculty of Science, Eastern University, Sri Lanka.

\title{
STORAGE EVALUATION OF COOKIES PRODUCED FROM COMPOSITE BLENDS OF WHEAT AND SWEET POTATO FLOUR
}

\author{
Jemziya $^{1}$, M.B.F., and Mahendran, $\mathrm{T}^{2}$ \\ ${ }^{1}$ Department of Biosystems Technology, Faculty of Technology, South Eastern \\ University of Sri Lanka, Oluvil. \\ ${ }^{2}$ Department of Agricultural Chemistry, Faculty of Agriculture, Eastern University, \\ Sri Lanka.
}

\begin{abstract}
A study was conducted to develop incorporated wheat and sweet potato flour cookies and to assess the quality of cookies during storage. Different composite blends of wheat flour and sweet potato ( $\mathrm{cv}$. Wariapola Red) flour were mixed in the ratios of 100:00, 80:20, 60:40, 40:60, 20:80 and 00:100, were then developed. These cookies were packed in sealed laminate aluminum foil. Cookies were stored under ambient conditions of average temperature of $30+1{ }^{\circ} \mathrm{C}$ and relative humidity 75-80 \% for evaluation of the shelf life. Cookies were subjected to quality assessments at two week intervals for the entire storage period of 6 months. Among the treatment, the composite superior cookies supplemented with $40 \%$ sweet potato flour contained $1.75 \%$ ash, $4.15 \%$ fiber, $5.42 \%$ fat, $6.76 \%$ protein and $84.4 \%$ soluble carbohydrate at the end of 12 weeks of storage. However, moisture content of these cookies increased from 1.35 to $2.01 \%$ which is within acceptable range for long term storage. The results of organoleptic assessment revealed that there were no significant differences $(p<0.05)$ between the treatments in terms of colour, mouth feel and overall acceptability while taste and texture had significant differences $(p>0.05)$ among the tested treatments. From the results of quality assessments, $40 \%$ composite cookies could be stored in above mentioned conditions for a minimum period of 12 weeks without any significant changes in the quality attributes.
\end{abstract}

Keywords: Cookies, nutritional quality, organoleptic evaluation, sweet potato, wheat flour

${ }^{1}$ Corresponding author: fathimajemziya @yahoo.com 


\section{INTRODUCTION}

Sweet potatoes (Ipomoea batatas) are absolutely loaded with nutrition and considered to be one of nature's most perfect vegetables. Among the world's major food crops, sweet potato produces the highest amount of edible energy per hectare per day [1]. Sweet potato consists of about $70 \%$ carbohydrates (dry basis) of which a major portion is starch, which can be utilized as a functional ingredient in certain food preparations. They are an excellent source of vitamin A (in the form of $\beta$-carotene) and also a very good source of vitamin $\mathrm{C}$ and manganese. In addition, sweet potatoes are a good source of dietary fiber, natural sugars, protein, niacin, vitamin $\mathrm{B}_{5}$, vitamin $\mathrm{B}_{6}$, vitamin $\mathrm{E}$, potassium, biotin, iron, calcium and copper.

Sweet potato is commonly referred to a subsistence, food security or famine relief crop. Its uses have diversified considerably in the developing countries. Sri Lanka has a long history of sweet potato cultivation. It is considered as a crop of exotic origin, but people regard it as indigenous because it has been in cultivation in Sri Lanka as an important traditional food crop from very ancient time [2]. Options for sweet potato products are numerous, and based on recent diagnostic assessments carried out in developing countries; dried chips, starch and flour were identified as among the most promising [3], [4]. Fresh sweet potato roots are bulky and highly perishable therefore sweet potato roots can be sliced, dried and ground in order to produce flour that remains in good condition for a long time. Sweet potato, either fresh, grated, cooked and mashed, or made into flour, could with high potential for success, replace the expensive wheat flour in making buns, chapatis (flat unleavened bread) and mandazis (doughnuts).

Mixture of wheat flour and sweet potato flour could make a good baking product, which should increase its economic value [5]. Most of the technical research on sweet potato flour has been focused on the development of new products using sweet potato flour rather than on efficient methods to produce and store the flour [6], [1]. Addition of various proportion of sweet potato flour in wheat flour can increase the nutritive values in terms of fiber and carotenoids. This also helps in lowering the gluten level and prevent from coeliac disease [7]. Sweet potato based products are of high quality and could compete with existing products in the market [8]. The use of sweet potato flour for supplementing with wheat flour on the baking could substantially reduce the need for wheat being imported, reduction in the usage of sugar on the products and increase the value of sweet potato. 
Our approach in the present study is to replace the wheat flour in cookies by sweet potato flour (gluten-free flours) in order to increase the fiber and other nutrients and developing cookies resembles as closely as possible to the wheat flour based product. The textural property and sensory quality of cookies are taken into consideration to improve the quality of cookies and also to reduce the postharvest losses of sweet potato by making sweet potato flour suitable for local conditions and to propose suitable sweet potato value added products and recipes that can be made from sweet potato flour.

\section{MATERIALS AND METHODS}

\subsection{Procurement of Materials}

Good qualities of sweet potatoes (cv. Wariapola Red) without any bruises were procured locally from the field of commercial grower after harvesting. Roots were washed, trimmed and cured to make them free from soil and other foreign materials, rotting, insect damage. Trimming was carried out manually and curing was done at $35{ }^{\circ} \mathrm{C}$ for 2-3 days, stored at $12-15^{\circ} \mathrm{C}$ at $80 \%$ relative humidity till further use. Other major ingredients that are wheat flour, sugar, baking powder, salt and margarine were purchased from a wholesale merchant from Batticaloa.

\subsection{Preparation of Sweet Potato Flour}

Good qualities of sweet potatoes (cv. Wariapola Red) were washed, peeled and cut into thin slices at around $1 \mathrm{~mm}$ thickness. Drying of sweet potato slices was done on perforated trays in the sun until the pieces were quite brittle and then stored in air tight container till further use. The dried chips were milled into flour using electric grinder and passed through sieves $(250 \mu)$ to obtain flour of uniform size. The flour was then packed in air tight container and stored under ambient conditions until further use.

\subsection{Experimental Plan}

$\mathrm{T}_{1}$ - Cookies made from $100 \%$ wheat flour $(0+100 \mathrm{~g})$

$\mathrm{T}_{2}-20 \mathrm{~g}$ Sweet potato flour $/ 100 \mathrm{~g}$ mixture $(20+80 \mathrm{~g})$

$\mathrm{T}_{3}-40 \mathrm{~g}$ Sweet potato flour $/ 100 \mathrm{~g}$ mixture $(40+60 \mathrm{~g})$

$\mathrm{T}_{4}-60 \mathrm{~g}$ Sweet potato flour $/ 100 \mathrm{~g}$ mixture $(60+40 \mathrm{~g})$

$\mathrm{T}_{5}-80 \mathrm{~g}$ Sweet potato flour $/ 100 \mathrm{~g}$ mixture $(80+20 \mathrm{~g})$

$\mathrm{T}_{6}$ - Cookie made from $100 \%$ sweet potato flour $(100+0 \mathrm{~g})$ 


\subsection{Development of Wheat and Sweet Potato Blend Cookies}

Cookie dough was prepared according to the following formula: $100 \mathrm{~g}$ of flour (contain different proportion of sweet potato flour and wheat flour), $50 \mathrm{~g}$ of sugar, $20 \mathrm{~g}$ of margarine, $2 \mathrm{~g}$ of baking powder, $0.5 \mathrm{~g}$ of sodium chloride and various proportion of water to make required consistency of dough. The firm dough was rolled out to $5 \mathrm{~mm}$ thickness in a baking tray and cut into round having $7.4 \mathrm{~cm}$ diameter with a cookie cutter. The cookies were placed on a greased aluminum tray and baked in a pre-heated oven at $200{ }^{\circ} \mathrm{C}$ for 10 minutes to produce cookies. These cookies were assessed for physico-chemical and organoleptic qualities.

\subsection{Package, Storage and Shelf Life Evaluation}

The cookies were packed in sealed laminate aluminum foil which is commercially used to pack the cookies. Cookies packs were stored under ambient conditions of average temperature of $30{ }^{\circ} \mathrm{C}$ and relative humidity $75-80 \%$ for 6 months. The shelf life of cookies was examined based on the nutritional and sensory qualities once in two weeks.

\section{RESULTS AND DISCUSSION}

\subsection{Nutritional Composition of the Freshly Made Sweet Potato Flour}

The results of nutritional composition of sweet potato flour are closely related with the results obtained by researchers in 2008 [1]. The moisture content of sweet potato flour was $8.1 \%$. Sweet potato flour had fiber content $9.4 \%$. This high fiber increases the utility of sweet potato flour in various food products and also had lesser extent of protein content $2.3 \%$ compared to the wheat flour $12.6 \%$. Most non wheat flours have less protein but higher carbohydrate content than wheat flour [9], [10]. 


\subsection{Shelf Life Evaluation of Composite Flour Cookies}

Based on the physical, nutritional and sensory analysis of freshly made wheat-sweet potato cookies, the most preferred wheat-sweet potato cookies were selected for storage studies.

\section{Treatment}

\section{Flour Composition}

\begin{tabular}{ll}
\hline $\mathrm{T}_{2}$ & $20 \mathrm{~g}$ Sweet potato flour $/ 100 \mathrm{~g}$ mixture \\
\hline $\mathrm{T}_{3}$ & $40 \mathrm{~g}$ Sweet potato flour $/ 100 \mathrm{~g}$ mixture \\
\hline $\mathrm{T}_{4}$ & $60 \mathrm{~g}$ Sweet potato flour $/ 100 \mathrm{~g}$ mixture \\
\hline
\end{tabular}

\subsection{Nutritional qualities of wheat-sweet potato cookies during storage}

\subsubsection{Moisture Content}

Nutrient content of all treatments have very little changes throughout the storage period. Certain researcher reported the moisture content in baked goods vary from 4 to $7 \%$ [11]. According to DMRT, moisture content increased significantly $(p<0.05)$ likewise, ash, fat, protein and fiber content decreased significantly $(p<0.05)$ throughout the storage period (Figure 1).

Cookies are hygroscopic nature. In case of moisture content, $\mathrm{T}_{2}$ and $\mathrm{T}_{3}$ have the slow rate of increasing trend than $\mathrm{T}_{4}$ ( $60 \%$ sweet potato flour added cookie). In the $\mathrm{T}_{3}$, there was no significant difference from $4^{\text {th }}$ to $10^{\text {th }}$ weeks of storage period.

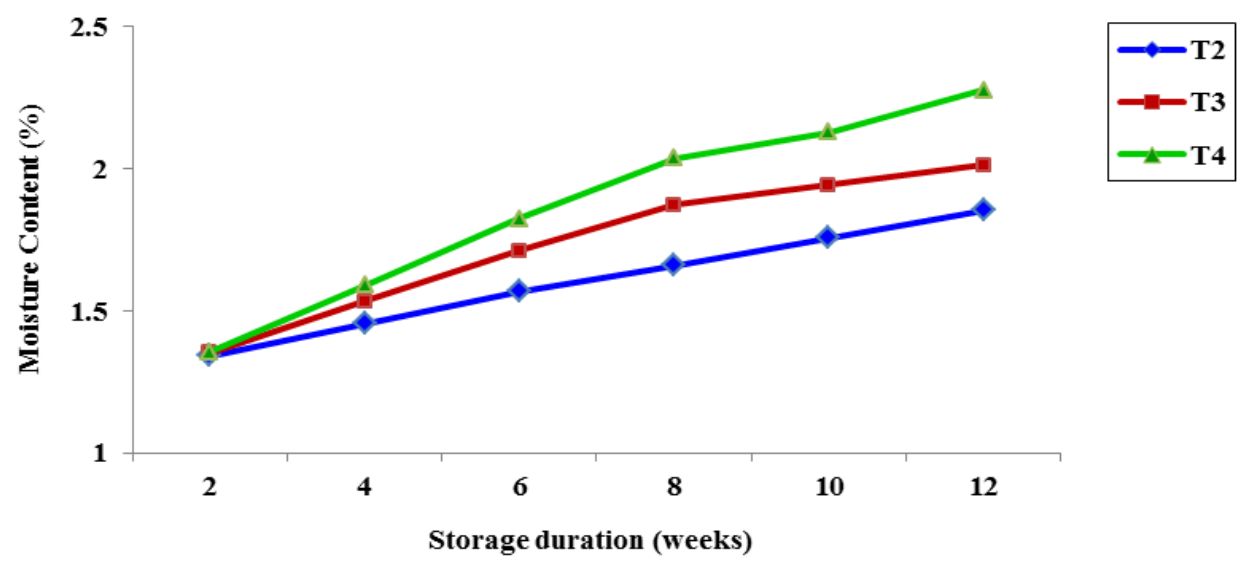

Values are means of triplicates

Figure 1: Changes in Moisture Content of Wheat-Sweet Potato Cookies during Storage 


\subsubsection{Ash Content}

Ash content of $T_{4}$ has the very slow rate of decreasing trend than $T_{2}$ and $T_{3}$ and there was no significant difference in ash content of $\mathrm{T}_{4}$ throughout the storage duration. Mineral losses may occur by heat - induced chemical reactions between reducing sugars and amino acids or proteins to form compounds that bind minerals. Considerable amounts of some soluble minerals are also dissolved in the water. This also leads to mineral loss throughout the storage period due to hygroscopic nature of the product. Likewise packaging can alter the food composition and thus influence mineral bioavailability.

\subsubsection{Fat Content}

Sweet potatoes are one of the limited fat content sources. Fat can help leaven a product due to incorporation of air [12]. Shortening of fat or oil contribute to the tenderization of baked products through inhibition of gluten development and starch gelatinization. This is through a water proofing effect, possibly due to the complex with the carbohydrate and/or protein. Lipid oxidation is one of the major causes of food spoilage. As shown in Figure 2, the treatment $\mathrm{T}_{3}$ has the very slow rate of decreasing trend than all other treatments. There were no significant differences in all treatments from $4^{\text {th }}$ week until the end of the study period.

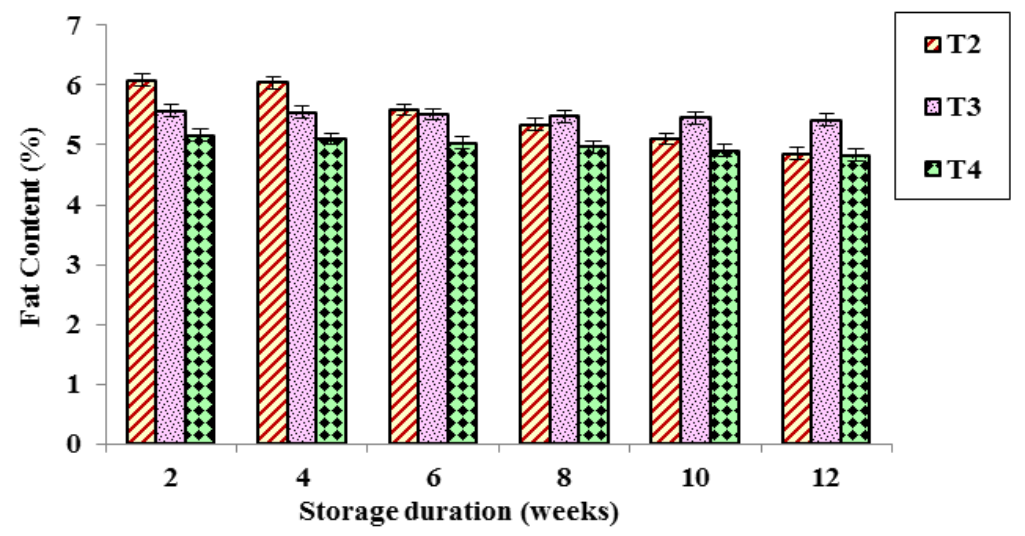

Values are means of triplicates

Vertical bars indicate the standard errors.

Figure 2: Changes in Fat Content of Wheat-Sweet Potato Cookies during the storage 


\subsubsection{Fiber Content}

Fiber content in all treatments has very little changes during the storage period shown in Figure 3. Processes involving heat-treatment may affect the dietary fiber in different ways. An increased temperature leads to a breakage of weak bonds between polysaccharide chains.

Reactions during processing that may affect the dietary fiber content and its properties are leakage into the processing water, formation of Maillard reaction products thus adding to the lignin content and formation of resistant starch fractions. Even though, $\mathrm{T}_{3}$ has the very slow rate of decreasing trend than all other treatments. There was no significant difference in fiber content of $\mathrm{T}_{4}$ from $4^{\text {th }}$ week until the end of the study period.

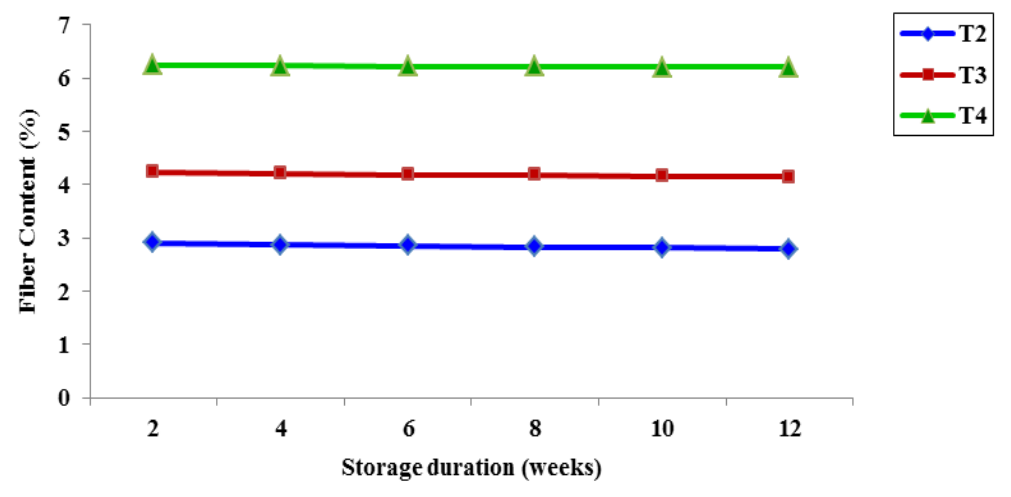

Values are means of triplicates

Figure 3: Changes in Fiber Content of Wheat-Sweet Potato Cookies during Storage

\subsubsection{Protein Content}

The various flour proteins present in wheat and sweet potato can undergo changes such as protein cross-linking, protein-carbohydrate interactions and protein denaturation during processing and storage of foods, non-enzymatic reaction may cause food deterioration and reduce the shelf life [13]. The changes in protein of the cookies during the storage are shown in Figure 4.

Treatment $T_{2}$ and $T_{3}$ have the very slow rate of decreasing trend than $T_{4}$. There were no significant differences in all treatments throughout the study period. This may occur due to interaction between reducing sugars and amino acids (Maillard reaction) and it is a major cause of quality change and degradation of nutritional content in many foods. 


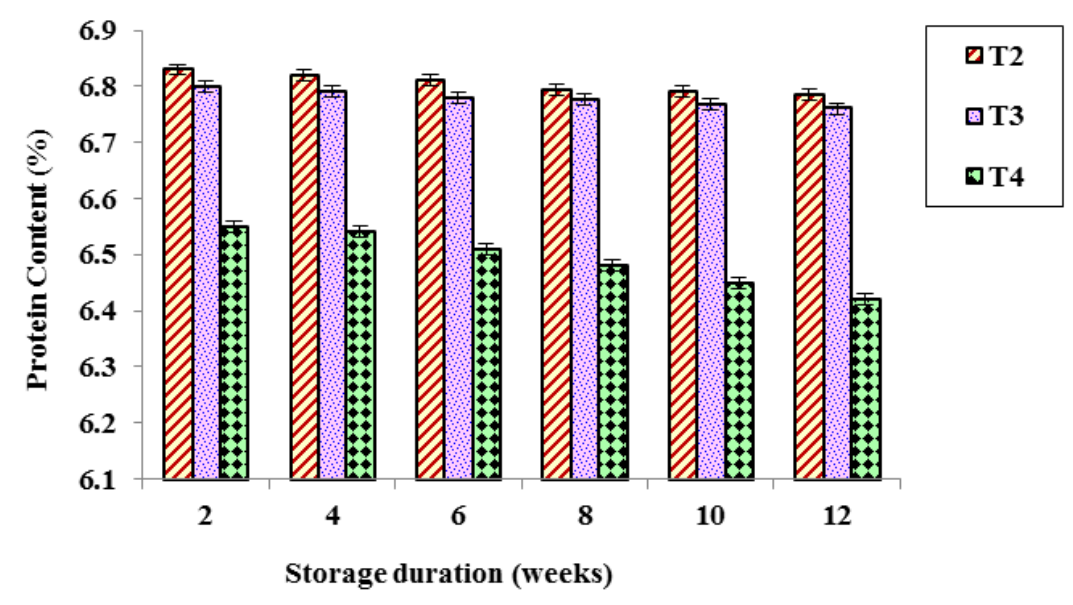

Values are means of triplicates

Vertical bars indicate the standard errors.

Figure 4: Changes in Protein Content of Wheat-Sweet Potato Cookies during Storage

\subsection{Sensory Analysis of Wheat-Sweet Potato Cookies Following Storage}

Organoleptic characteristics of the cookies were changed slightly following the storage period. This may be due to the non-enzymatic browning reaction (Maillard reaction) and fat oxidation. Development of off flavours as a result of oxidation, particularly fats. During the storages of food, Maillard reaction has impact on sensory qualities [14].

The $40 \%$ sweet potato flour added cookie $\left(\mathrm{T}_{3}\right)$ has the best shelf life in based on the nutritional and organoleptic point of view compared to other combinations of wheat and sweet potato flour. Mean values of sensory attributes of stored wheat-sweet potato cookies are shown in Table 1. 
Table 1: Sensory Analysis of Wheat-Sweet Potato Cookies following Storage

\begin{tabular}{cccccc}
\hline Treatments & Texture & $\begin{array}{c}\text { Mouth } \\
\text { feel }\end{array}$ & Taste & Colour & $\begin{array}{c}\text { Overall } \\
\text { acceptability }\end{array}$ \\
\hline $\mathbf{T}_{\mathbf{2}}$ & $4.52 \pm 0.11^{\mathrm{b}}$ & $4.40 \pm 0.12^{\mathrm{a}}$ & $4.30 \pm 0.15^{\mathrm{b}}$ & $4.65 \pm 0.10^{\mathrm{a}}$ & $4.35 \pm 0.11^{\mathrm{a}}$ \\
\hline $\mathbf{T}_{\mathbf{3}}$ & $4.82 \pm 0.05^{\mathrm{a}}$ & $4.25 \pm 0.15^{\mathrm{a}}$ & $4.50 \pm 0.11^{\mathrm{ab}}$ & $4.80 \pm 0.07^{\mathrm{a}}$ & $4.60 \pm 0.11^{\mathrm{a}}$ \\
\hline $\mathbf{T}_{\mathbf{4}}$ & $4.42 \pm 0.11^{\mathrm{b}}$ & $4.16 \pm 0.15^{\mathrm{a}}$ & $4.80 \pm 0.07^{\mathrm{a}}$ & $4.75 \pm 0.08^{\mathrm{a}}$ & $4.50 \pm 0.11^{\mathrm{a}}$ \\
\hline
\end{tabular}

The values are means of 20 replicates \pm standard error.

The means with the same letters are not significantly different from each other at $5 \%$ level based on.

From the overall acceptance rating, the $40 \%$ sweet potato flour added cookie has the highest mean value and no remarkable changes in organoleptic characters were observed up to three months of storage in ambient condition of average temperature $30{ }^{\circ} \mathrm{C}$ and relative humidity of $75-80 \%$, indicate that the $40 \%$ sweet potato flour added cookies could be preserved up to three months. Tukey's Studentized Range (HSD) Test. The sensory attributes were analyzed in ranking test with the values from 1 to 4.9 . The $40 \%$ sweet potato flour added cookie $\left(\mathrm{T}_{3}\right)$ has the best shelf life in nutritional and organoleptical point of view compared to other combinations of wheat and sweet potato flour. From the overall acceptance rating, the $40 \%$ sweet potato flour added cookie has the highest mean value and no remarkable changes in organoleptic characters were observed up to three months of storage in ambient condition of average temperature $30{ }^{\circ} \mathrm{C}$ and relative humidity of $75-80 \%$, indicate that the $40 \%$ sweet potato flour added cookies could be preserved up to three months.

\section{CONCLUSIONS}

Sweet potatoes are an excellent source of nutrition and very productive crop among other vegetable crops. In this regard, this study was carried out to reduce the wastage and improve the utilization of sweet potato through the year. The finding of the research revealed that sweet potato contains considerable amount of protein, rich in dietary fiber and carbohydrate, therefore a successful combination with wheat flour for 
cookies production would be nutritionally advantageous. Therefore, 20, 40 and $60 \%$ sweet potato flour incorporated cookies were selected as the best combinations based on the nutritional and organoleptic characters. Among the tested treatments, $40 \%$ sweet potato flour incorporated cookies have the best shelf life and have highly acceptable functional, nutritional and organoleptic quality characters compared to other combinations and no remarkable changes were observed up to 12 weeks of storage in ambient condition of average temperature $30{ }^{\circ} \mathrm{C}$ and relative humidity of $75-80 \%$, indicating that the $40 \%$ sweet potato flour added cookies could be stored up to 12 weeks. Blending sweet potato flour with wheat flour up to $40 \%$ level produced cookies which can be used for production of bakery foods with improved functional properties using innovative processing methods according to their specific and distinct functional and nutritional properties. The use of sweet potato flour for supplementing with wheat flour on the baking could substantially reduced need for wheat being imported, reduction in the usage of sugar on the products and increase the value of sweet potato. The outcome of this research could be used as valuable information for the development of high fiber-low gluten sweet cookies.

\section{REFERENCES}

[1] Sukhcharn, S., Riar, C. S., and Saxena, D. C., (2008). Effect of incorporating sweet potato flour to wheat flour on the quality characteristics of cookies. African Journal of Food Science. 2: 65-72.

[2] Karunathilake, E. K., (2005). Horticulture Vegetable Science (Vegetables, Tubers, and Spice crops), 120-122.

[3] Collins, M., (1989). Economic Analysis of Wholesale Demand for Sweet potatoes in Lima, Peru. M.Sc. Thesis. Department of Agricultural and Resource Economics, University of Florida, Gainesville, USA, 1-164.

[4] Okorie, S. U., and Onyeneke, E. N., (2012). Production and quality evaluation of baked cake from blend of sweet potatoes and wheat flour. Part-I: Natural and Applied Sciences.3:2-10.

[5] Zuraida, N., (2003). Sweet potato as an alternative food supplement during rice shortage. Journal Lit bang Pertanian. 22: 4-11.

[6] Lizado, M. L. C., and Guzman, M. P., (1982). Development of new products using sweet potato flour. Economic Journal. 10(1): 62-69.

[7] Tilman, J. C., Colm, M. O. B., Denise, M. C., Anja, D., and Elke, K. A., (2003). Influence of gluten free flour mixes and fat powder on the quality of gluten free 
biscuits. European Journal of Food Research and Technology, 216: 369-376.

[8] Sneha, S., Genitha, T. R., and Vrijesh, Y., (2012). Preparation and Quality Evaluation of Flour and Biscuit from Sweet Potato. Journal of Food Processing and Technology. 3:12-21.

[9] Tindall, H. D., (1968). Commercial vegetable growing. Oxford: oxford university press, 234-279.

[10] Okorie, S. U., and Onyeneke, E. N., (2012). Production and quality evaluation of baked cake from blend of sweet potatoes and wheat flour. Part-I: Natural and Applied Sciences, 3:2-11.

[11] Manley, D. J. R., (1998). Biscuit, Cookies and Crackers Manufacturing, Manual No VI: Packaging and Storing. $3^{\text {rd }}$ Ed., Wood head Publishing Limited, England, 5-37.

[12] Brooker, B., (1998). The Role of Fat in biscuits: Strategy for Fat reducing products. Wood Head publishers, Cambridge, UK. 127-168.

[13] Singh, R. P., (2000). Scientific principles of shelf life evaluation. In: Shelf life Evaluation of Foods. $2^{\text {nd }}$ ed. Man, D. and Jones, A. (Ed.). Aspen publishers. Inc., Gaithersburg, Maryland, 3-4.

[14] Fennema, O. R., (1996). Food chemistry. $3^{\text {rd }}$ ed. CRC Press. Wisconsin, USA, $157-412$. 